\title{
Epidemiologien ved juvenil idiopatisk artritt og andre artritter $\mathrm{i}$ barnealderen
}

\author{
Berit Flatø og Odd Vinje \\ Revmatologisk avdeling, Rikshospitalet
}

\section{ENGLISH SUMMARY}

Flatø B, Vinje O. The epidemiology of juvenile idiopathic arthritis and other types of childhood arthritis. Nor J Epidemiol 2008; 18 (1): 93-98.

\begin{abstract}
Seventeen to 20 percent of children with recent onset arthritis have juvenile idiopathic arthritis (JIA). The annual incidence of JIA in Norway ranges from 14-23/100000 children according to population based prospective studies. In other Scandinavian countries an incidence of 11 to 19/100000 has been found in epidemiological studies. A point prevalence of JIA of 86-148/100000 has been found. The varying results may have been influenced by differences in the classification or exclusion criteria used, varying referral bias and limited population samples studied. They may also represent time trends or geographic variations. Female gender, knee or small joint involvement, a positive antinuclear antibody, high platelet counts and genetic factors have been associated with the development of JIA in children with undifferentiated early arthritis. Further studies of large populations over time are necessary to reveal true geographic variations in the frequency of JIA, based on genetic or environmental factors.
\end{abstract}

\section{INNLEDNING}

Juvenil idiopatisk artritt (JIA), også kalt barneleddgikt, er den hyppigste kroniske revmatiske sykdommen i barnealderen. Diagnosen er en utelukkelsesdiagnose og tilstander som septisk artritt, artritt i samband med osteomyelitt og post-infeksiøs artritt må utelukkes. Majoriteten av barn med nyoppstått artritt har en selvbegrensende (transient) leddbetennelse som går over i løpet av få dager eller uker. Tidlig identifisering av de som har barneleddgikt har betydning for å oppnå et optimalt resultat av en økende tilgang på effektive behandlingsalternativer.

I Skandinavia er der spesielt gode muligheter for å studere epidemiologien ved JIA fordi et homogent offentlig helsevesen med jevnlige gratis helsekontroller gjør at de fleste barn med vedvarende artritt blir fanget opp og henvist til videre utredning.

\section{KLASSIFIKASJONSKRITERIER FOR KRONISK ARTRITT I BARNEALDEREN}

De første beskrivelser av kronisk artritt hos barn ble gjort i 1864 (1). Kriterier for diagnose og klassifisering av artritt hos barn ble første gang foreslått av de britiske legene Ansell og Bywaters (2). De brukte initialt navnet Stills sykdom som et samlebegrep for alle typer barneleddgikt. Senere foreslo de å begrense Stills sykdom til den systemiske formen for barneleddgikt, karakterisert av svingende feber og utslett. Betegnelsen juvenil polyartritt ble anbefalt for tilstander der leddaffeksjonen dominerte. Den amerikanske revmatologiforeningen (ACR) utarbeidet kriterier for juvenil revmatoid artritt (JRA) i 1972, revidert i 1977 (3). Mens amerikanerne holdt seg til begrepet JRA brukte europeerne samlebetegnelsen juvenil kronisk artritt (JCA). I regi av European League Against Rheumatism (EULAR) ble det i Oslo i 1977 utarbeidet klassifikasjonskriterier for JCA (4). Kriteriene skiller seg mhp. varighet av symptomer, eksklusjonskriterier og antall undergrupper (Tabell 1). Det ble tidlig klart at barneleddgikt var en heterogen sykdomsgruppe, og på 90-tallet vokste det fram et økende behov for å komme fram til internasjonalt aksepterte definisjoner av homogene former for barneleddgikt for å fremme kommunikasjon, forskning og behandling. "International League of Associations of Rheumatologists" (ILAR) oppnådde i 1997 enighet om å bruke samlebetegnelsen juvenil idiopatisk artritt (JIA) for ulike undergrupper av barneleddgikt (5). Det ble utviklet klassifikasjonskriterier for 7 undergrupper. Disse undergruppene representerer pasienter med ulikheter med hensyn på genetiske predisposisjoner, prognose og behandlingseffekt (6-10).

Artritt defineres som hevelse $i$ et ledd eller innskrenket leddbevegelighet kombinert med varme, leddsmerte eller ømhet der andre årsaker til leddforandringene er ekskludert $(3,5)$.

\section{INSIDENS AV TIDLIG UDIFFERENSIERT ARTRITT HOS BARN}

Forekomsten av spekteret av nyoppståtte artritter er undersøkt i noen få studier, hovedsakelig ifra Skandinavia. Riise og medarbeidere fant en årlig insidens på 71 tilfeller av artritt per 100000 barn under 16 år i Oslo, Akershus og Buskerud fylke i en fersk studie (Tabell 2) (11). En årlig insidens på 109/100000 barn ble funnet $i$ en studie fra Helsinki i 1985 (12). Disse populasjonsbaserte studiene hadde en sammenlignbar 
Tabell 1. Klasifikasjonskriterier for barneleddgikt.

\begin{tabular}{llll}
\hline Kriterier & ACR & EULAR & ILAR \\
\hline Terminologi & Juvenil revmatoid artritt (JRA) & Juvenil kronisk artritt (JCA) & Juvenil idiopatisk artritt (JIA) \\
Debutalder & $<16$ år & $<16$ år & $<16$ år \\
Varighet av artritt & $\geq 6$ uker & $\geq 3 \mathrm{mndr}$ & $\geq 6$ uker \\
Inkluderte undergrupper & Systemisk & Systemisk & Systemisk \\
& Polyartikulær & Polyarticulær & Polyartikulær RF- \\
& Pauciartikulær & & Polyartikulær RF+ \\
& & Pauciarticulær & Oligoartikulær, persisterende \\
& & & Oligoarticulær, extended \\
& & Psoriasis artritt & Psoriasis artritt \\
& & Juvenil Bekhterev & Entesitt relatert artritt \\
& & Artritt ved IBD & Ikke klassifiserbar artritt \\
Ekskluderte undergrupper & Juvenil Bekhterev & & \\
& Juvenil psoriasis artritt & & \\
& Artritt ved IBD & & \\
\hline
\end{tabular}

$\mathrm{ACR}=$ American College of Rheumatology, EULAR $=$ European League Against Rheumatism, ILAR $=$ International League Association of Rheumatologists, IBD = inflammatorisk tarmsykdom, RF = rheumatoid faktor

Tabell 2. Årlig insidens av nyoppstått artritt hos barn i populasjonsbaserte studier.

\begin{tabular}{|c|c|c|c|c|c|c|c|c|}
\hline \multirow[b]{2}{*}{ Forfatter } & \multirow{2}{*}{$\begin{array}{c}\text { År } \\
\text { publisert }\end{array}$} & \multirow[b]{2}{*}{ Sted } & \multirow[b]{2}{*}{$\mathrm{n}$} & \multirow{2}{*}{$\begin{array}{l}\text { Insidens/ } \\
\text { 100000/år }\end{array}$} & \multicolumn{3}{|c|}{ Insidens av ulike typer artritt $/ 100000$} & \multirow{2}{*}{$\begin{array}{c}\text { Andel } \\
\text { JIA/JCA }\end{array}$} \\
\hline & & & & & JIA/JRA & Transient & Infeksiøs & \\
\hline Riise et al & 2007 & Norge* & 182 & 71 & 14 & 52 & 5 & $20 \%$ \\
\hline Kunnamo et al & 1985 & Finland $\dagger$ & 161 & 109 & 19 & 83 & 7 & $17 \%$ \\
\hline Von Koskull et al & 2001 & Tyskland & 319 & 87 & 7 & 76 & & $8 \%$ \\
\hline Savolainen et al & 2003 & Finland\# & 11 & 64 & 23 & 41 & & $36 \%$ \\
\hline
\end{tabular}

*Oslo, Akershus og Buskerud fylke † Helsinki \# Kuopio

design der primærleger ved gjentatte henvendelser ble bedt om å henvise barn med mistenkt artritt til ett av to til tre sykehus. Diagnosen ble satt på bakgrunn av kliniske, biokjemiske, serologiske og mikrobiologiske undersøkelser. Den lavere forekomst av artritt hos barn i Øst-Norge enn i Finland kan ha sammenheng med at alle barn ble undersøkt med ultralyd og konvensjonell røntgen i den norske studien. Dette kan ha ført til en mer presis diagnostisering. På den annen side ble en høyere forekomst $(88 / 100000)$ funnet i Oslo by enn $\mathrm{i}$ forstadsområdene i Akershus (70/100000) og i det mer landlige Buskerud (45/100000). Forekomsten av barneleddgikt var imidlertid lik i alle tre fylker. Dette kan tyde på at færre milde tilfeller ble henvist til sykehus når avstanden mellom bosted og sykehus var lang og at flere tilfeller forble udiagnostisert i Øst-Norge enn i Helsinki. Det kan imidlertid ikke utelukkes at forekomsten av nyoppstått artritt hos barn er lavere i ØstNorge enn i Helsinki eller at forekomsten har blitt redusert i løpet av de siste tjue år f.eks. som følge av endret vaksinasjonsstatus.

En insidens av nyoppstått artritt sammenlignbar med den i Øst-Norge ble funnet i Sør-Tyskland og i en liten finsk studie $(13,14)$. En høy andel barn med barneleddgikt kan tyde på en overhyppighet av barn med alvorlig og langvarig artritt $\mathrm{i}$ denne finske studien. Den tyske studien var basert på spørreskjemaer til primærleger, og reliabiliteten av diagnostiseringen kan ha vært influert av begrenset erfaring med juvenil artritt blant legene.

Sytten til tjue prosent av barn med nyoppstått artritt har barneleddgikt $(11,12)$.

\section{INSIDENS AV BARNELEDDGIKT}

En årlig insidens av barneleddgikt på 14 per 100000 barn under 16 år ble funnet i den prospektive populasjonsbaserte studien av barn med nyoppstått artritt $i$ Oslo, Akershus og Buskerud (Tabell 3) (11). Høyere insidenstall, 19-23/100 000, ble funnet i en retrospektiv og en prospektiv befolkningsbasert studie i Troms, Finnmark og Sør-Trøndelag (10,15). Epidemiologiske studier fra andre land i Skandinavia har vist en årlig insidens per 100000 på 19-21 i Helsinki og 11-15 i Sverige $(10,12,16-18)$.

Systematiske undersøkelser med hensyn på tegn til postinfeksiøs artritt kan ha ført til en mer utbredt eksklusjon av pasienter med postinfeksiøs artritt, særlig mhp. Borrelia og streptokokkassosiert artritt, i den Øst-Norske enn i de andre studiene. Ultralydundersøkelse av alle barn med mistenkt artritt i Øst-Norge (11) kan ha ført til en mer utbredt eksklusjon av pasienter 
Tabell 3. Forekomsten av barneleddgikt i Skandinavia.

\begin{tabular}{ccllccc}
\hline $\begin{array}{l}\text { Referanse } \\
\text { nr. }\end{array}$ & År utgitt & Kilde & Område & Term & $\begin{array}{c}\text { n/ risiko- } \\
\text { populasjon }\end{array}$ & $\begin{array}{c}\text { Insidens/ } \\
100000 \text { barn }\end{array}$ \\
\hline 15 & 1998 & Sykehus, retrospektiv & Troms og Finnmark & JCA* & $109 / 48.215$ & 23 \\
10 & 2003 & Populasjon, prospektiv & Troms og Finnmark & JIA $\dagger$ & $14 / 49.060$ & 19 \\
& & & & $19 / 54788$ & 23 \\
11 & 2007 & Populasjon, prospektiv & Oslo, Akershus, Buskerud & JIA\# & $36 / 255.303$ & 14 \\
16 & 1992 & Populasjon, prospektiv & Sverige, vest & JCA* & $213 / 389.976$ & 11 \\
10 & 2003 & Populasjon, prospektiv & Sverige & JIA $\dagger$ & $122 / 536.457$ & 15 \\
& & & Danmark, øst & JIA $\dagger$ & $41 / 310.699$ & 9 \\
& & & Danmark, Århus & JA $\dagger$ & $29 / 123.218$ & 16 \\
12 & 1986 & Populasjon, prospektiv & Finland, Helsinki & JRA\# & $82 / 148.362$ & 19 \\
17 & 1996 & Register, prospektiv & Finland & JRA\# & $114 / 264.226$ & 14 \\
18 & 2001 & Register, prospektiv & Finland & JRA\# & $87 / 445.856$ & 20 \\
10 & 2003 & Populasjon, prospektiv & Finland, Helsinki & JIA $\dagger$ & $82 / 264.134$ & 21 \\
\hline
\end{tabular}

* Artritt ikke definert

\# Artritt = hovent ledd eller bevegelsesinnskrenket ledd i kombinasjon med hevelse, varme eller ømhet

$\uparrow$ Varme og smertefulle ledd inkludert i definisjonen artritt

med manglende objektive tegn til synovitt eller hydrops sammenliknet med studiene fra Midt- og Nord-Norge $(10,15)$. Inklusjon av pasienter med varme og ømme ledd uten andre tegn til artritt (10) eller retrospektiv identifisering av tilfeller (15) kan ha øket insidenstallene i studiene fra Midt- og Nord-Norge. På den annen side kan det ikke utelukkes at der har vært flere uidentifiserte tilfeller av artritt $i$ et noe mer mangeartet helsevesen i Øst- enn i Nord- og MidtNorge. Ved en sjelden sykdom som barneleddgikt vil undersøkelser av relativt små populasjoner kunne ha ført til variasjon i resultatene $\mathrm{i}$ de norske studiene $(10,11,15)$. Internasjonalt er det i populasjonsbaserte studier funnet gjennomsnittlig 13 nye tilfeller av barneleddgikt per 100000 barn per år (19). Flere prospektive studier av store befolkningsgrupper over tid med presis diagnostistering er nødvendige for å avdekke om der er en spesielt høy insidens, geografiske forskjeller og/eller variasjoner over tid når det gjelder forekomsten av JIA i Norge.

\section{Prevalens aV barneleddgikt}

Prevalensen av barneleddgikt er funnet å være 148/ 100000 barn i Troms og Finnmark (15) og 86/100000 i Vest-Sverige (16). Internasjonalt varierer prevalensratene sterkt, fra 8-400/100000 barn per år (19). Praktiske problemer i forhold til undersøkelser av store befolkningsgrupper, ulik diagnostisering og manglende kriterier for definisjon av aktiv sykdom har gjort undersøkelser av prevalensen av JIA vanskelige å gjennomføre.

\section{DEMOGRAFI OG SYKDOMSKARAKTERISTIKA VED ARTRITT HOS BARN}

Det er funnet en overvekt av jenter ved JIA (omlag $60 \%$ ) mens jenter er $\mathrm{i}$ mindretall ved septisk, post- infeksiøs og transient artritt (om lag 40\%) $(11,12)$. En topp i insidensraten for JIA er funnet ved 1 til 3 års alder (Figur 1), særlig hos jenter. Hos jenter er der også funnet en økning i insidensraten ved alder 10-13 år $(10,11)$. Postinfeksiøs artritt har en maksimal forekomst ved 7 års alder og er sjelden funnet før 3-4 års alder (11). De fleste barn med septisk artritt er under 3 år mens transient artritt oppstår i hele barnealderen.

Knær har vært de hyppigst affiserte ledd ved debut av JIA etterfulgt av ankler (Figur 2). Hofteleddsaffeksjon har sjelden vært det presenterende funn ved JIA og kunne snarere tyde på en transient artritt $(11,12)$. Vel $60 \%$ av barn med barneleddgikt hadde mindre enn 5 affiserte ledd i løpet av de første 6 måneders sykdomsvarighet (10-12). Polyartritt er sjelden påvist ved andre artrittformer enn JIA (20).

\section{FAKTORER SOM PREDISPONERER FOR JIA}

Tvillingstudier har tydet på at der er en genetisk komponent i predisposisjonen for JIA. Begge tvillinger var affisert av JIA hos $44 \%$ av eneggede og $4 \%$ av toeggede tvillingpar (21). Øket forekomst av visse HLA alleler i det såkalte "Major Histocompatibility Complex" (MHC) på kromosom 6 har støttet genetiske faktorers betydning i predisposisjonen for JIA. Disse faktorer er fundamentalt forskjellige fra de som predisponerer for revmatoid artritt (RA) hos voksne. Den viktigste faktoren er HLA-DR8 som har vært øket ved de fleste undergrupper av JIA (oligoartritt, polyartritt og entesittrelatert artritt) $(6,22,23)$. HLA-B27 har vært sterkt assosiert til juvenil entesittrelatert artritt (juvenil spondylartropati) $(8,22)$.

I de senere år har assosiasjoner med ikke-HLA alleler vært påvist, for eksempel gener som koder for proinflammatoriske cytokiner og cytokinreseptorer (IRF-1, TNF- $\alpha$, IL-1Ra, IL-6, MIF) (24). Videre har 


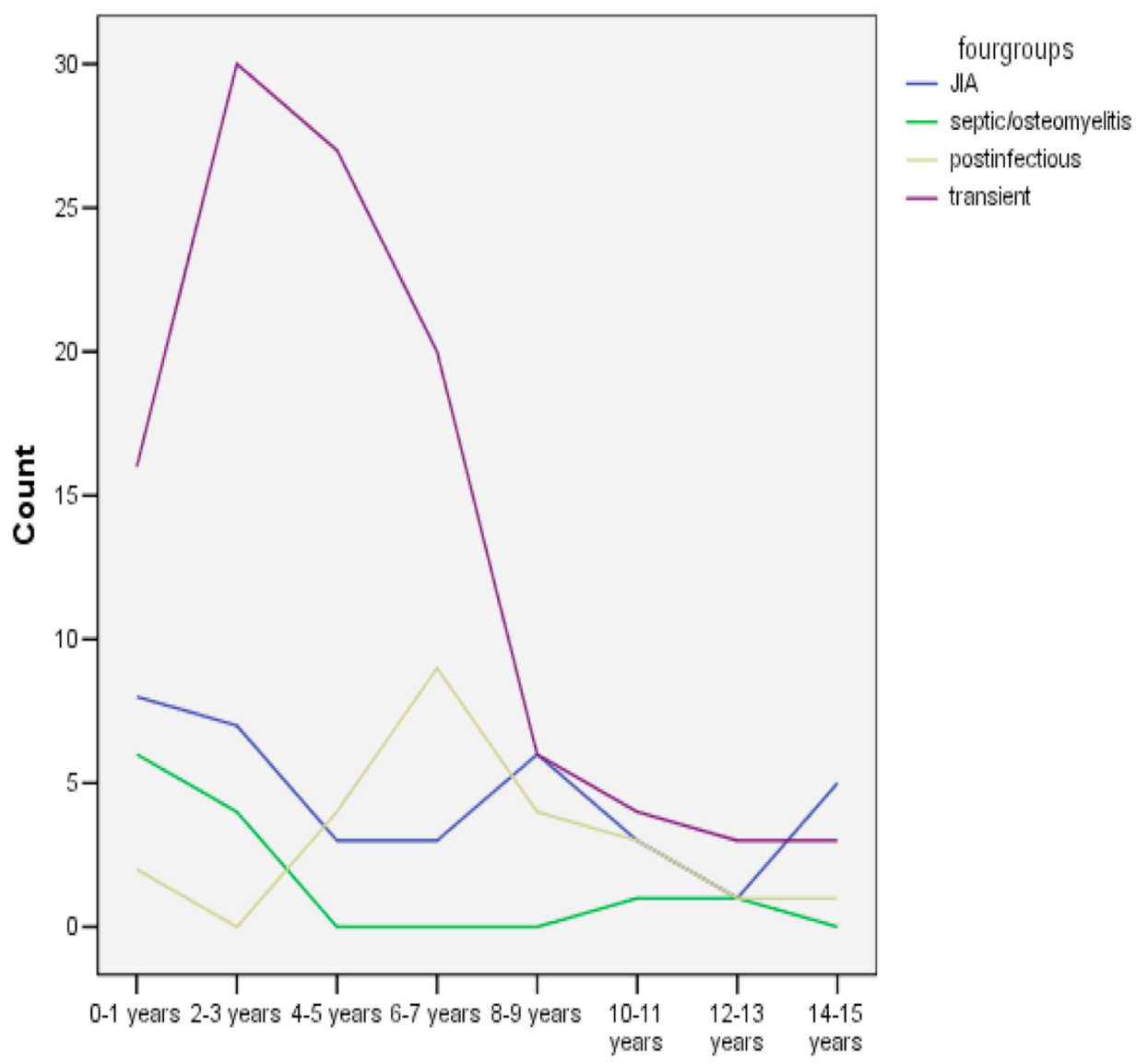

Figur 1. Debutalder ved ulike former for artritt hos barn. Gjengitt med tillatelse fra Riise 2007 (ref 11).

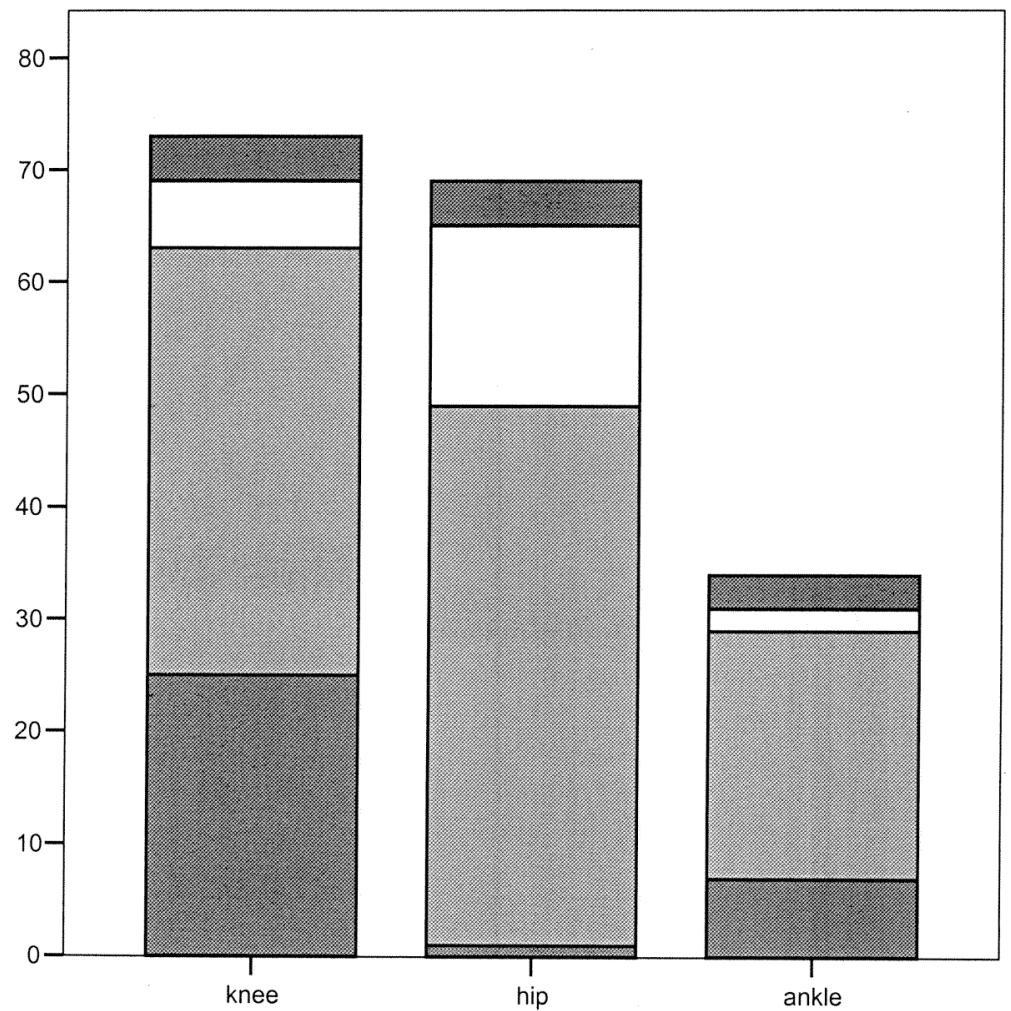
Artritis
- $\mathrm{JIA}$
Transient
$\square$ Postinfectious
Infectious

Figur 2. Leddaffeksjon ved debut av JIA og andre former for artritt. Gjengitt med tillatelse fra Riise 2007 (ref 11). 
genetiske markører assosiert med andre autoimmune sykdommer også vært funnet i overhyppighet ved JIA $(24,25)$.

Forhøyet antall trombocytter og tilstedeværelse av antinukleært antistoff (ANA) har blitt assosiert med utvikling av JIA hos barn med nyoppstått udifferensiert $\operatorname{artritt}(20)$.

\section{MORTALITET VED JIA}

Dødeligheten ved JIA var 2\% i løpet av 15 års sykdomsvarighet $\mathrm{i}$ en norsk etterundersøkelse (26). I denne aldersgruppen var 15 års dødelighet under en prosent $\mathrm{i}$ den generelle norske befolkning i samme tidsperiode (27). I et landsdekkende finsk register var dødeligheten ved JIA 2-3 ganger forventet dødelighet i befolkningen (28). I denne studien var en tredjedel av dødsfallene relatert til barneleddgikt (hjerteaffeksjon og amyloidose). Infeksjoner og intoksikasjoner var også relativt hyppige dødsårsaker. En 5-doblet økning i forventet dødelighet hos kvinner og en 3-doblet økning hos menn med barneleddgikt ble funnet $i$ et nasjonalt register i Skottland (29). Raten for observert versus forventet dødelighet var høyere ved JIA enn ved RA i samme register.

\section{KONKLUSJON}

Opp til $20 \%$ av barn med nyoppstått artritt har JIA. Insidensen av barneleddgikt er 14-23/100000 barn i Norge. Prevalensen av sykdommen er 86-148/100000. Kvinnelig kjønn, kne- eller småleddsaffeksjon, positiv ANA, høyt trombocyttall, og visse genetiske merkestoffer er assosiert med utvikling av JIA. Ytterligere studier av store befolkningsgrupper over tid er nødvendig for å avdekke om der er sanne geografiske forskjeller i forekomsten av barneleddgikt, på basis av genetiske eller miljømessige faktorer.

\section{REFERANSER}

1. Cornil MV. Memoire sur les coincidences pathologiques du rheumatisme articulaire chronique. C R Mem Soc Biol (Paris) 1864; 3: 3-25.

2. Ansell BM, Bywaters EG. Prognosis in Still's disease. Bull Rheum Dis 1959; 9 (9): 189-92.

3. Brewer EJJ, Bass J, Baum J, Cassidy JT, Fink C, Jacobs J et al. Current proposed revision of JRA Criteria. JRA Criteria Subcommittee of the Diagnostic and Therapeutic Criteria Committee of the American Rheumatism Section of The Arthritis Foundation. Arthritis Rheum 1977; 20 (2 Suppl): 195-9.

4. Wood PHN. Nomenclature and classification of arthritis in children. In: Munthe E, ed. The care of rheumatic children. Basel: EULAR publishers, 1978: 47-50.

5. Petty RE, Southwood TR, Manners P, Baum J, Glass DN, Goldenberg J et al. International League of Associations for Rheumatology classification of juvenile idiopathic arthritis: second revision, Edmonton, 2001. $J$ Rheumatol 2004; 31 (2): 390-2.

6. Smerdel A, Ploski R, Flato B, Musiej-Nowakowska E, Thorsby E, Forre O. Juvenile idiopathic arthritis (JIA) is primarily associated with HLA-DR8 but not DQ4 on the DR8-DQ4 haplotype. Ann Rheum Dis 2002; 61 (4): 354-7.

7. Selvaag AM, Lien G, Sorskaar D, Vinje O, Forre O, Flato B. Early disease course and predictors of disability in juvenile rheumatoid arthritis and juvenile spondyloarthropathy: a 3 year prospective study. J Rheumatol 2005; 32 (6): 1122-30.

8. Flato B, Hoffmann-Vold AM, Reiff A, Forre O, Lien G, Vinje O. Long-term outcome and prognostic factors in enthesitis-related arthritis: a case-control study. Arthritis Rheum 2006; 54 (11): 3573-82.

9. Kimura Y, Pinho P, Walco G, Higgins G, Hummell D, Szer I et al. Etanercept treatment in patients with refractory systemic onset juvenile rheumatoid arthritis. J Rheumatol 2005; 32 (5): 935-42.

10. Berntson L, Andersson GB, Fasth A, Herlin T, Kristinsson J, Lahdenne P et al. Incidence of juvenile idiopathic arthritis in the Nordic countries. A population based study with special reference to the validity of the ILAR and EULAR criteria. J Rheumatol 2003; 30 (10): 2275-82.

11. Riise OR, Handeland KS, Cvancarova M, Wathne KO, Nakstad B, Abrahamsen T et al. Incidence and characteristics of arthritis in Norwegian children - A population based prospective multi centre study. J Pediatr (In press).

12. Kunnamo I, Kallio P, Pelkonen P. Incidence of arthritis in urban Finnish children. A prospective study. Arthritis Rheum 1986; 29 (10): 1232-8.

13. von Koskull S, Truckenbrodt H, Holle R, Hormann A. Incidence and prevalence of juvenile arthritis in an urban population of southern Germany: a prospective study. Ann Rheum Dis 2001; 60 (10): 940-5.

14. Savolainen E, Kaipiainen-Seppanen O, Kroger L, Luosujarvi R. Total incidence and distribution of inflammatory joint diseases in a defined population: results from the Kuopio 2000 arthritis survey. J Rheumatol 2003; 30 (11): 2460-8. 
15. Moe N, Rygg M. Epidemiology of juvenile chronic arthritis in northern Norway: a ten-year retrospective study. Clin Exp Rheumatol 1998; 16 (1): 99-101.

16. Gare BA, Fasth A. Epidemiology of juvenile chronic arthritis in southwestern Sweden: a 5-year prospective population study. Pediatrics 1992; 90 (6): 950-8.

17. Kaipiainen-Seppanen O, Savolainen A. Incidence of chronic juvenile rheumatic diseases in Finland during 1980-1990. Clin Exp Rheumatol 1996; 14 (4): 441-4.

18. Kaipiainen-Seppanen O, Savolainen A. Changes in the incidence of juvenile rheumatoid arthritis in Finland. Rheumatology 2001; 40 (8): 928-32.

19. Oen KG, Cheang M. Epidemiology of chronic arthritis in childhood. Semin Arthritis Rheum 1996; 26 (3): 575-91.

20. Handeland KS, Riise OR, Wathne KO, Nakstad B, Flatø B. Early prediction of JIA in childhood arthritis. Arthritis Rheum 2007; 56 (9 suppl): 379.

21. Nepom B. The immunogenetics of juvenile rheumatoid arthritis. Rheum Dis Clin North Am 1991; 17 (4): $825-$ 42.

22. Ploski R, Flato B, Vinje O, Maksymowych W, Forre O, Thorsby E. Association to HLA-DRB1*08, HLADPB $1 * 0301$ and homozygosity for an HLA-linked proteasome gene in juvenile ankylosing spondylitis. Hum Immunol 1995; 44 (2): 88-96.

23. Flato B, Smerdel A, Johnston V, Lien G, Dale K, Vinje O et al. The influence of patient characteristics, disease variables, and HLA alleles on the development of radiographically evident sacroiliitis in juvenile idiopathic arthritis. Arthritis Rheum 2002; 46 (4): 986-94.

24. Phelan JD, Thompson SD, Glass DN. Susceptibility to JRA/JIA: complementing general autoimmune and arthritis traits. Genes Immun 2006; 7 (1): 1-10.

25. Smerdel A, Dai KZ, Lorentzen AR, Flato B, Maslinski S, Thorsby E et al. Genetic association between juvenile rheumatoid arthritis and polymorphism in the SH2D2A gene. Genes Immun 2004; 5 (4): 310-2.

26. Flato B, Lien G, Smerdel A, Vinje O, Dale K, Johnston V et al. Prognostic factors in juvenile rheumatoid arthritis: a case-control study revealing early predictors and outcome after 14.9 years. J Rheumatol $2003 ; 30$ (2): 386-93.

27. Statistisk sentralbyrå. Befolkningsstatistikk 1997, hefte 2. 1997.

28. Savolainen A, Isomaki H, Myllykangas-Luosujarvi R, Aho K. Trends in mortality of patients with rheumatoid arthritis. J Rheumatol 2000; 27 (9): 2283-4.

29. Thomas E, Symmons DP, Brewster DH, Black RJ, Macfarlane GJ. National study of cause-specific mortality in rheumatoid arthritis, juvenile chronic arthritis, and other rheumatic conditions: a 20 year followup study. $J$ Rheumatol 2003; 30 (5): 958-65. 